\title{
8 Nigeria's role in the ECOWAS Peace and Security Agenda for West Africa
}

\author{
Oshita O. Oshita and Warisu Oyesina Alli
}

\section{Introduction}

The West Africa sub-region has faced a lot of security challenges, particularly in the past three decades. The first major security challenge was the Liberian crisis which rapidly deteriorated into a civil war that threatened the entire sub-region. While the Liberian civil war was going on, the political crisis in neighbouring Sierra Leone quickly grew into a civil war, influenced no doubt by the events in Liberia. Guinea also experienced grave political upheaval. Not far away, Côte d'Ivoire also had its national political conflict, which developed out of a protracted political succession crisis. Guinea-Bissau, Togo, Niger, Burkina Faso, and Mali, one after the other, were consumed by political conflicts that, in most cases, ended in major internal disturbances and in some cases civil wars. Indeed, the Mano River Union region, in particular, was in the form of a political conflagration. The occurrence of so many violent conflicts in the sub-region, particularly in the last decade, would suggest that the conflict prevention mechanisms and preventive diplomacy of the Economic Community of West African States (ECOWAS) have mostly been ineffective.

In all cases, ECOWAS's peace and conflict resolution mechanisms were activated in response to such developments. However, ECOWAS's interventions, which would necessarily begin with mediation and were mostly diplomatic, were found to be inadequate and in need of military support in terms of peace support operations (PSOs), provision of humanitarian assistance, conflict resolution, and peacebuilding efforts. These are tasks the sub-regional organisation has not been well equipped to carry out successfully, mainly because of its weak resource base. It is therefore almost inevitable that Nigeria, which has a gross domestic product (GDP) that is much more than the GDP of all the other ECOWAS members combined, has had to shoulder a lot of responsibilities in providing the leadership, as well as the human and material resources, needed for ECOWAS interventions in the many conflicts in the sub-region. Nigeria's regional leadership is also defined and determined by its demography and possession of many critical elements of power, including a strong military, moral imperatives, and the political will to take on the challenge. There are also the security concerns of the country for subregional peace. 


\section{Conflicts and development of peace support operations}

ECOWAS was established in 1975 as a regional organisation for the promotion of economic cooperation and integration. The organisation comprised at inception 16 countries, which have now been reduced to 15 since the withdrawal of Mauritania in 2000. The sub-region has a diverse colonial history, with the countries being either former British, French, or Portuguese colonies. Also, the sub-region has had the highest incidence of military coups and interventions in civilian politics in Africa.

As West Africa experiences rapid transformation, democratisation, and population growth, security challenges have continued to threaten its progress. Even though the original mandate of ECOWAS focused on regional economic integration as a way to enhance economic stability and development, it was, however, immediately apparent to ECOWAS members that the organisation's lofty goals could only be achieved in an atmosphere of peace and stability. Accordingly, two protocols on defence were signed shortly after the creation of the community. These were the Protocol on Non-Aggression (1978) and the Protocol on Mutual Assistance on Defence (1978). The two documents were designed to address the understanding at the time that threats to security could only emanate from the external environment. The documents empowered ECOWAS to intervene in armed conflict in any of its member states if the conflict was likely to endanger peace and security in the entire community.

The collapse of the economies of many West African countries in the wake of the introduction of Structural Adjustment Programmes (SAP) in the 1980s, the end of the Cold War, and negative effects of globalisation, coupled with the nature of authoritarian domestic politics, led to political crises in many West African states, leading to state collapse and civil wars and conflicts in Liberia, Sierra Leone, Guinea-Bissau, Mali, Niger, Côte d'Ivoire, and Burkina Faso.

The Liberian crisis, which started in 1989, provided an opportunity for ECOWAS members to demonstrate their commitment to the ideals of the mutual assistance protocol, especially on the request of Liberian President Samuel Doe for intervention. ECOWAS could not accede to this request because of the different positions of Francophone and Anglophone states. While the Francophone countries supported the rebel leader, Charles Taylor, the Anglophone countries supported Doe. To overcome this stalemate, the ECOWAS Standing Mediation Committee, which was dominated by the Anglophone countries, with Nigeria in the lead, met in Banjul, the Gambia, and agreed to send an intervention force, the ECOWAS Cease-fire Monitoring Group (ECOMOG), to Liberia.

In the absence of any response from the international community to the conflict and massive violations of human rights in the country, ECOMOG came to save the day. The idea of deploying ECOWAS troops in Liberia was mooted by Nigeria, against the wishes of many other members, particularly Francophone countries.

In August 1997, ECOMOG's mandate was extended to Sierra Leone to reinstate the democratically elected government of President Ahmad Tejan Kabbah, 
which was overthrown by the military, and to restore peace, security, and democracy in that country.

In 1998, ECOMOG foreign ministers recommended that ECOMOG formally become responsible for peacekeeping operations in the region. ECOWAS subsequently enhanced its capacity and slowly transformed ECOMOG from a series of ad hoc initiatives to a more permanent structure for sustained military cooperation and operation.

The lessons learned from intervention in Liberia (1990-1997), Sierra Leone (1997-2000), and Guinea-Bissau (1999) were later to shape the creation of the ECOWAS Mechanism for Conflict Prevention, Management, Resolution, Peacekeeping, and Security in 1999, also referred to as "the Mechanism," which went beyond the earlier protocols of 1978 and 1981 in that it allowed a situation whereby ECOWAS could intervene in internal conflicts that posed security threats to the region, including the overthrow of, or threats to, democratically elected governments. ECOWAS has had to intervene in Côte d'Ivoire, Mali, and several other crisis situations across the sub-region. ECOWAS has been designated as one of the five regional pillars of the African Economic Community (AEC), together with the Common Market for Eastern and Southern Africa (COMESA), the Economic Community of Central African States (ECCAS), the Intergovernmental Authority on Development (IGAD), and the Southern African Development Community (SADC).

In 2001, ECOWAS member countries signed the Supplementary Protocol on Democracy and Good Government, which complements the Mechanism in addressing the root causes of conflict, instability, and insecurity. Earlier, in July 1993, a revised ECOWAS treaty, designed to accelerate cooperation, was signed, while in January 2007 the ECOWAS Secretariat was transformed into the ECOWAS Commission as part of a wider institutional reform of the community.

Notwithstanding the challenges of ECOWAS's economic integration, the 1990s saw the development and institutionalisation of a formal peace and security architecture to facilitate regional peacekeeping, PSOs, and conflict management interventions. The Mechanism was the realisation of this objective and was also aimed at shifting emphasis from conflict management, which is a reactive intervention, to a proactive conflict prevention framework.

\section{Role of Nigeria}

The role of Nigeria in PSOs in West Africa has largely been determined by its size and resources, as well as its security concerns. Thus, it has played a prominent leadership role in ECOWAS and a significant role in ECOMOG, contributing significant numbers of troops for peacekeeping deployments to Liberia (19901997), Sierra Leone (1997-2003), Guinea-Bissau (1998), Côte d'Ivoire (2003), and Mali (2014). Nigeria also led a Multinational Joint Task Force (MNJTF) with Niger and Chad (2015) to tackle the insurgency by the Islamic group Jama'atu Ahlis Sunna Lidda'awati Wal Jihad [People Committed to the Propagation of the Prophet's Teachings and Jihad], better known as Boko Haram. 
One of the realities of the political landscape of West Africa is the clear, unquestionable, and transparent preponderance of Nigeria as the leading and hegemonic local actor in the sub-region (Akindele, 2003). This has informed the development of its military capability. The consequence has been aggressive investment and modernisation to improve the nation's military power, including its composition, equipment, leadership, and doctrine (Bassey, 1993). This capability of Nigeria in the military and economic spheres defines the role it plays in regional security policy and operations.

Adebajo (2002) has described Nigeria's role in West Africa as hegemonic. Even ECOWAS member states which have benefitted from its generosity only grudgingly accept its leadership (Adebajo, 2008, 3). There is a dilemma for Nigeria in that West African states are not prepared to replace a colonial yoke with a Nigerian one. As pointed out by Fawole (2008), even though President Ibrahim Babangida declared that Nigeria was one country that every other country in West Africa and Africa in general looked up to, to provide the desired leadership, the Francophone states, in particular, and other states in the sub-region, in general, view Nigeria with suspicion. They therefore enter into other forms of security arrangements - for their self-pride and protection (Danjuma, 2012). Hence, the view expressed by Adebajo (2002) that Nigeria's leadership position has become a kind of affliction. And the fear and suspicion that Nigeria has imperialist designs on its neighbours seem to be another challenge to Nigeria's West Africa policy (Akindele, 2003, 287).

Considering all the problems facing West African states, there is a need to establish a security regime in the area and a hegemon is required to propel the security regime and Nigeria fits that description. But there are still other problems, because Nigeria is yet to develop the capacity and legitimacy to influence the sub-region and fail sometimes to convince other states to follow its lead on vital political and security and economic issues. Of course, it is not as simple as that because there are other forces at work; for example, other regional powerhouses, such as Senegal, Côte d'Ivoire, Burkina Faso, Ghana, and others, and even extrasub-regional interests competing for influence in West Africa.

Generally, however, by whatever yardstick sub-regional leadership is measured, Nigeria is a core state, defined as a state whose economic size is sufficiently large to be capable of successfully going it alone in industrialisation and economic development. Its population, natural resource endowments, and market size and intensity make economy of scale realisable; and Nigeria is recognised by its neighbours as the economic, financial, and diplomatic centre of the sub-region (Akindele, 2003, 282).

Nonetheless, Nigeria's role is also determined by its interests, which are strategic in nature. These interests are also linked to the fact that a sizable number of its citizens reside in other African states and it has undertaken to protect the lives of its nationals anywhere as part of its defence policy objectives, since regional crises impact directly on Nigeria and Nigerians. There are also social and economic interests, which include the resources it has invested in maintaining peace (Adedeji, 2007, 199). 
Nigeria's security, according to former minister of foreign affairs Ojo Maduekwe $(2008,6)$, is therefore inexorably linked to a more secure Africa; a continent that is peaceful and prosperous, a continent that is respected and courted, not just for its previous contributions to world civilisation, but for the advancement of humankind into the twenty-first century and beyond. Hence, Nigeria could find justification to not only contribute but to also provide leadership, including the use of its military, to control any instability in the sub-region, as a way of protecting its own interests.

It thus became imperative for Nigeria to organise and develop an effective diplomatic and military backbone with which to support its national objectives, taking account of the risks (FGN, 2006, 3). As part of this commitment to subregional security, Nigeria created the Ministry of Cooperation and Integration in Africa (MCIA) in 1999 with a Department of Collective Defence and Security and Department of Regional Economic Integration. The MCIA, under which the Institute for Peace and Conflict Resolution also functioned, was also made the focal point for ECOWAS, thus showing the high level of the nation's commitment to West African integration. This arrangement allowed more attention to be given ECOWAS peace and security matters than used to be the case. However, in 2007 as part of the civil service reforms, President Olusegun Obasanjo merged the MCIA with the Ministry of Foreign Affairs.

Nigeria's geostrategic location also plays a role in defining the nation's security focus. Situated in a region of comparatively much smaller and weaker states, in terms of size, human, and material resources, Nigeria's security focus could be said to have been pre-determined (Alli, 2012). As a result, all Nigerian leaders have come to accept that responsibility for sub-regional security rests on their shoulders.

In common with most members of the United Nations (UN), Nigeria subscribes to the ideals of "collective security" at global, continental, and sub-regional levels. Accordingly, West African security, Nigeria believes, can only be guaranteed by policies of cooperation, economic integration, and adoption of consensus (Ajibewa, 2007, 18).

Justifying Nigeria's involvement in PSOs and in regional security policy, Gambari (2010) observed that

in Africa, lack of sustainable development has been linked directly to the proliferation and intensity of conflict situations and war which in turn have hampered development efforts [...] threats to peace in a neighbouring country, if not carefully managed and resolved could lead to massive exodus of refugees, weapons proliferation and trans-border crimes and general insecurity that could threaten other stable polities and compromise national economies.

Thus, Nigeria could be appropriately considered a driver of security policy in West Africa. This is because, as argued by Adedeji $(2007,198)$, in this loosely structured defence system only Nigeria has the size, experience, and logistical 
resources to serve as the core of an ECOWAS rapid deployment force with broad objectives.

The personal diplomatic efforts of Nigerian leaders, from Generals Yakubu Gowon, Ibrahim Babangida, Sani Abacha, and Abdusalam Abubakar to Presidents Obasanjo, Umar Yar'Adua, Goodluck Jonathan, and Muhammadu Buhari, have been quite significant. Obasanjo, as civilian president (1999-2007), was active in these conflict resolution efforts. President Umar Yar'Adua followed Nigeria's traditional role and at the same time furthered what Ojo Maduekwe, his foreign minister, called citizen diplomacy, but with a more audacious rendition of the perspective, guided by diplomacy of consequence, which means reciprocity (Akinterinwa, 2010). Jonathan also continued to shoulder this self-imposed responsibility for the maintenance of peace and security in West Africa, getting very involved in the Mali crisis.

The general direction of Nigerian involvement is informed by a broadly defined foreign policy objective built on a national role perception, articulated and documented in the National Defence Policy (2006). It is informed by a conventional perspective on security threats, and the capacity for rapid response and deployment (Bamali, 2007, 96).

The main features of Nigeria's West Africa policy derive from the paradigms of Nigerian foreign policy, including African centrepiece perspective, the concentric circle model, and the beneficial concentricism. The 1999 Constitution of Nigeria, as amended in Section 19, projects a dynamic foreign policy for Nigeria through the promotion of economic development, integration and unity, and peace and security in Africa and the world. Accordingly, Nigeria's involvement in West African security affairs and any role it might have played in the past few decades have been the result of strongly held opinions by its successive leaderships. Generally, it has been a role that acknowledges the nation's responsibility for Africa, which the public has come to accept, though with reservations. This was the basis for Babangida's famous declaration in 1985, as quoted by Ajulo $(1998,18)$, that "Africa's problems and their solution, should constitute the premise of Nigeria's foreign policy." This idea was echoed by Jonathan (2011), who, at the opening of a National Conference on the Review of Nigerian Foreign Policy organised by the Presidential Advisory Council (PAC) in August 2011, noted that

In the era of globalisation, at a time of grave challenges to national and international security such as we face from terrorism and transnational criminal networks, our commitment to regional and international peace and security must remain as strong as ever.

In line with this, the Federal government Vision:2020 prescribes an elaborate mandate for the Nigerian Foreign Service including ensuring that Nigeria's leading role in Africa and in the West African sub-region is sustained and safeguarded.

Ironically, the establishment of ECOWAS remains one of the greatest achievements of Nigerian diplomacy up to 1990 and has remained the embodiment of "Pax Nigeriana" (Adebajo, 2008, 1). 
In furtherance of its security management capabilities, Nigeria has finally developed what is considered a comprehensive National Defence Policy. The high-powered committee on national defence policy, headed by the late Gen. Joe Garba, director-general of the National Institute for Policy and Strategic Studies (NIPSS), was empanelled in 2000 by Gen. T. Y. Danjuma, then defence minister. Though work on the Nigeria National Defence Policy (NNDP) started immediately, it was only finally adopted in 2006.

The NNDP enunciates general guidelines for the employment of the armed forces, in particular, and national resources, generally, to maintain the country's territorial integrity and protect it from external aggression. It is aimed at providing compact, flexible, and above all battle-winning armed forces. It provides direction for the development of defence organisations, together with other elements of power for the security of Nigeria (FGN, 2006, 2), and is well integrated and managed in order to serve national security objectives in response to perceived threats.

Notwithstanding what Nigeria may have put in place, there are institutional weaknesses within ECOWAS including inadequate resources, lack of administrative and military capability, and poor political will and commitment by members, all of which militate against and indeed undermine Nigeria's leadership role. While it appears the military components are being progressively addressed, the non-military components have not been properly articulated in a manner that is responsive to the emerging security challenges at home and in the sub-region. In addition, the use of militarism instead of socio-economic and political engineering to address security matters is no longer appropriate for the kind of security challenges being faced domestically and in the sub-region as a whole.

\section{Peacekeeping and peace support operations}

About half of the West Africa population is Nigerian; the GDP of Nigeria amounts to about 60 per cent of the sub-region's regional GDP. According to Deng $(2009,26)$,

Leadership of the regional organisation and lead nations, in particular the dominant state, Nigeria, is key to the effectiveness of ECOWAS in peace and security. General Yakubu's leadership of Nigeria in the 1970s was crucial to the establishment of ECOWAS. In the 1990s, the then Nigeria military leader, General Babangida, made it possible for ECOWAS to intervene in regional peace, conflict and security.

Nigeria is globally recognised as a major troop-contributing nation to UN peacekeeping operations around the world because of its readiness and commitment, which started even before the nation had gained independence, participating in UN peacekeeping operations in Congo in 1960. Since then, Nigeria has deployed troops for PSOs at bilateral, African Union (AU), ECOWAS, and UN levels, participating in Lebanon, Chad, Angola, Namibia, Cambodia, Yugoslavia, Somalia, Rwanda, Sudan (Darfur), and of course Liberia, Sierra Leone, Mali, and 
others - and also in observer missions. According to Gambari (2010), peacekeeping operations or PSOs have become for Nigeria a veritable instrument of foreign policy, an accent of the imperative to deter abroad acts that threaten its security, peace, and development.

Babangida, whose regime was confronted with the Liberia conflict, argued then that

The ECOWAS region completes what has been termed the three concentric circles governing Nigerian foreign and defence policies - There is therefore no gain saying [sic] the fact that when certain events occur in this region depending upon their intensity and magnitude, which are bound to affect Nigeria's politico-military and socio-economic environment, we should not stand-by as hapless and helpless spectators.

Nigeria in collaboration with others, in this sub-region, is duty bound to react or respond in an appropriate manner, necessary to either avert the disaster or to take adequate measures to ensure peace, tranquillity and harmony.

(Bassey, 2011, 7)

With ECOMOG's efforts under Nigeria's leadership, the Liberia conflict was eventually resolved and in August 1997 Charles Taylor was sworn in as president.

In many respects, the Sierra Leone conflict was a spill-over of the civil war in Liberia. On 25 May 1997, the Sierra Leonian military overthrew the government of President Tejan Kabbah. The UN, the AU, and ECOWAS were united in their demand for the Junta to return power back to the overthrown government. Rather than heed this call, the Junta went ahead and announced its cabinet. At ECOWAS meetings in Abidjan in June-July 1997, sanctions were imposed and some embargoes were also applied. ECOWAS was to formally approve the extension of the ECOMOG mandate to include Sierra Leone. Subsequently, the Nigerian government, which later became impatient with the pace of compliance with the various resolutions, ordered its troops to overturn the coup (Adeshina, 2002, 14). Nigerian troops were deployed, and they removed the Major Koromah Junta and Kabbah was reinstated in office in 1998. It was therefore Nigeria's immense contribution in troops, money, and material that made it possible for ECOWAS to achieve its objectives in the two countries. After ECOMOG's success in Sierra Leone, the UN established the United Nations Mission in Sierra Leone (UNAMSIL) in October 1999 as a peace-enforcement operation.

By 1999, it was estimated that Nigeria had committed over USD \$13 billion to peacekeeping operations in West Africa (Bamali, 2007, 100), since the beginning of the Liberian conflict in 1989. Over the years, there has been public outcry over the way and manner the Nigerian leadership waded into trouble spots in the sub-region without any tangible benefit to the country. Because of this, in 1998 Nigeria decided not to contribute troops to the ECOMOG mission in Guinea-Bissau (Galadima, 2011, 322). However, without Nigeria's participation, it was not surprising that the operation collapsed. 
After his inauguration as president in 1999, Obasanjo wanted to scale back Nigeria's commitment to sub-regional military engagements. In a speech to the 54th UN General Assembly in 1999, Obasanjo (2007, 40), noted that

For too long, the burden of preserving international peace and security in West Africa has been left almost entirely to a few states in the sub-region. Nigeria's continued burden in Sierra Leone is unacceptably draining Nigeria financially. For our economy to take off, this bleeding has to stop.

In the ECOMOG operation in Sierra Leone, Nigeria provided virtually everything ranging from aircraft hiring to the supply of food items.

A contingency operational allowance of $\$ 150$ per person was paid on a monthly basis to more than 10,000 soldiers throughout the period the operation lasted (i.e. from May 1997 to April 2000 when the UN took over the operation from Nigeria).

(Adeshina, 2002, 182)

Subsequently, Nigeria had to scale down rather than withdraw its troops in Sierra Leone, because of the strong pressure on the country to remain. General Abubakar, former military head of state, noted that Nigeria can claim a fair share of the glory for winning the peace that Sierra Leone went on to enjoy (Abubakar, 2009, 95). Nigeria participated in the UN Mission in Liberia (UNMIL) from 2003 until its completion in 2018. In this operation, according to Gen. Nuhu Bamali, Nigeria was left to transport its own troops and those of Gambia and Guinea for the ECOMOG operation in the capital Monrovia (Bamali, 2007).

The Côte d'Ivoire crisis presented a different kind of security challenge to ECOWAS. The keenly contested elections of October 2000 led to an intense power struggle between Laurent Gbagbo and his allies, on the one hand, and Gen. Robert Guéi on the other. After several years of prevarications, in 2010 another presidential election was conducted between Laurent Gbagbo and Alassane Ouattara and his supporters. This was against the background of an intense debate over ivoirité or "Ivorianness." The identity crisis turned violent following gun battles in the economic capital of Abidjan and elsewhere in the country in 2002. President Obasanjo despatched Nigerian Alfa fighter planes to foil a military coup d'état against Gbagbo, only to withdraw them soon thereafter. A rebellion led by disgruntled soldiers, under the name of the Patriotic Movement of Côte d'Ivoire (MPCI), soon made the situation worse, splitting the country into two. Nigeria was to provide buffer troops to separate the two warring groups, now identified as the Northern and Southern forces. This early intervention helped to dictate the direction of ECOWAS policy on the very complicated crisis.

At the request of President Gbagbo, ECOWAS deployed a peacekeeping force to monitor a ceasefire agreement between the warring forces. Nigeria was to contribute troops for the ECOWAS ceasefire monitoring assignment in the country in 
2002. Throughout 2003, Obasanjo undertook several missions across West Africa to ensure a unified approach to the Ivorian crisis.

In early February 2004, the UN Security Council (UNSC) Resolution 1527 approved the efforts of ECOWAS and France to "promote a peaceful settlement of the conflict" and also empowered the ECOWAS mission in Cote d'Ivoire to stabilise the nation. Later in the same month, UNSC Resolution 1528 established the UN Operation in Côte d'Ivoire (UNOCI) into which ECOWAS troops were later integrated. Meanwhile, Nigeria also contributed military observers to the Côte d'Ivoire operations just as Ambassador Ralph Uwechue of Nigeria was appointed the Special Representative of the ECOWAS Executive Secretary in Côte d'Ivoire to monitor and coordinate ECOWAS efforts in the country.

The complexity of the Ivorian crisis, according to Sanda (2003), "taught the Nigerian government to learn to take the backstage, and adopt a multilateral diplomatic approach instead." Hitherto, Nigeria used to wade into sub-regional internal political crises with a lot of enthusiasm, as demonstrated by Nigeria's role in Sierra Leone, which as Adeshina $(2002,154)$ points out was essentially a unilateral mission that was costly in terms of operation, finance, and human resources, and lost the country goodwill within the sub-region.

Nigeria has been able to provide logistics and funding at crucial moments in the organisation's history of conflict management, resolution, peace-keeping, and peacebuilding (Akindele, 2003). Over 70 per cent of ECOMOG troops and 80 per cent of the mission's funds were provided by Nigeria (Abubakar, 2009, 195). Agwai $(2010,132)$ observes that the major accolades the Nigerian army won in the cause of participating in some of the PSOs helped to project Nigeria's image as an emerging power in Africa and were an important factor in international politics, while Malu $(2009,174)$ asserts that without Nigeria's involvement and leadership, it is doubtful that peace could have been achieved.

However, Adeshina $(2002,154)$ cautions that

The decision by Nigeria to embark on the Sierra Leonean operation all alone was unnecessarily altruistic and unwise. Ghana and other countries that took active part during the various peace negotiations between the Junta Forces and government of Sierra Leone backed out when it came to the issue of using their Forces to remove the rebels from Freetown and the entire country.

In March 2012, junior officers of the Malian army under Capt. Ahmadou Sanogo executed a coup to overthrow the democratically elected government of President Amadou Toumani Touré. The rebel officers accused the government of failing to equip the military adequately for the fight against a Tuareg insurgency in the north of the country. Following this coup, the Tuareg rebels in the National Movement for the Liberation of Azawad (MNLA) and their allies in militant Islamist group Ansar Dine, backed by Al-Qaeda in the Magreb (AQIM), declared the establishment of the Islamic Republic of Azawad. 
ECOWAS immediately imposed a comprehensive embargo on the new Malian military regime, which, according to ECOWAS Chair and President of Côte d'Ivoire Alassane Ouattara, would only be lifted when constitutional order was restored in the country. When ECOWAS military chiefs met on 5 April at Abidjan to discuss the Malian crisis, it was agreed to activate the process for deployment of ECOWAS troops to "protect the unity and territorial integrity of Mali." The AU supported this decision of ECOWAS.

After overcoming several setbacks, the African-led International Support Mission to Mali (AFISMA) was launched in January 2013 with 3,300 troops. Nigeria provided 1,200 of them, while others came from Benin, Burkina Faso, Ghana, Guinea, Niger, Senegal, and Togo. Maj.-Gen. Shehu Abdulkadir of Nigeria was appointed force commander. It is important to note that without the significant Nigerian contingent, the ECOWAS stabilisation force in Mali would have suffered from a lack of personnel (Pryce, 2013, 29). AFISMA faced many logistical challenges from the beginning, including securing food, fuel, and water (Oluwadare, 2013, 116). In fact, France, which had been reluctant to intervene in the Malian crisis, had to move in when AFISMA troops were overrun by the rebels.

In May 2013, just a few months after AFISMA was deployed, UN SecretaryGeneral Ban Ki-Moon announced the reconstitution of AFISMA into the United Nations Multidimensional Integrated Stabilisation Mission in Mali (MINUSMA) with Maj.-Gen. Jean-Bosco Kazura of Rwanda as the new force commander. No Nigerian officer was appointed to the MINUSMA posts of deputy force commander, head of mission, or deputy head of mission. Also interestingly, MINUSMA received enormous logistical support from Belgium, Canada, France, the United Kingdom, and the United States. According to Oluwadare $(2013,118)$, AFISMA was a phantom force that was dead on arrival because of poor funding and inadequate troops, and was only resuscitated by MINUSMA.

Shortly thereafter, Nigeria announced the withdrawal of its troops from Mali. It was argued in some quarters that Nigeria withdrew its troops from Mali because the UN did not appoint a Nigerian as the force commander or in any of the leading positions in MINUSMA. However, the ECOWAS chair said he received a letter from President Jonathan that the withdrawal was in response to the need for the infantry to cope with a domestic situation in Nigeria (McGregor, 2013, 4). Truly, Nigeria was at that period in 2013 facing very serious challenges from the asymmetric Boko Haram insurgency. It should be noted, however, that although Nigeria pulled out its infantry from Mali, it left behind engineers and other specialist officers. Nigeria also withdrew two battalions from the African UnionUnited Nations Hybrid Operation in Darfur (UNAMID). The country, however, retained its troops in Guinea-Bissau as part of the ECOWAS Mission in Liberia (ECOMIL), a 620-strong contingent drawn from Nigeria, Senegal, and Burkina Faso (McGregor, 2013, 4).

The ECOMOG experience in regional peacekeeping and conflict management - and the enduring role of Nigeria in it - demonstrates the relevance of the role and contributions of sub-regional hegemons in the maintenance of regional 
peace and security. Despite reservations about Nigeria's preponderance, its presence in enforcement operations has contributed to the management of conflicts and restoration of stability. In general, the majority of West African states tend to accept Nigeria's leadership in regional peacekeeping, even though they are suspicious of it, and equally resent its unilateral military interventions. This illustrates that a sub-regional hegemon has to be sensitive to reservations among smaller member states in a collective security mechanism.

In fact, some ECOWAS members, particularly the Francophone states, perceiving ECOMOG as an instrument of Nigerian foreign and security policy, provided opportunities for extra-regional actors with strategic interests in West Africa to discourage some ECOWAS states from participating in the Nigeria-led regional peacekeeping force, hence undermining the effectiveness of ECOWAS in peace and security.

Initially, ECOMOG was a peacekeeping force. However, as conflicts became more intractable, its mission was re-designated, at the insistence of Nigeria, as a peace enforcement force. This was a historical development in the sense that it was clearly the first time such an initiative had been undertaken on the African continent. Nevertheless, it was an ad hoc mechanism. However, because of its success and usefulness, the framework was institutionalised in the Mechanism. ECOMOG became an intervention force under Article 17. It also provided for the composition of ECOMOG as a structure of "several stand-by multi-purpose modules (civilian and military) in their countries of origin and ready for immediate deployment." This is what is referred to as the ECOWAS Standby Force (ESF). The ESF has continued to undergo modifications to enhance its capability, mobility, and effectiveness when the need arises for deployment.

\section{Conclusion}

Nigeria has played an important role in the maintenance of peace and security in West Africa and particularly in the development and institutionalisation of a regional peace and security architecture and the commitment to collective security. However, Nigeria has its own domestic challenges due to unresolved socio-economic, political, and security issues. These domestic challenges constitute serious limitations to Nigeria's ability to continuously exert its influence in regional peace and security issues. A certain sense of clumsiness is also observed in the nation's intervention in security matters in West Africa because officials are sometimes lackadaisical and casual about issues.

With Nigeria's dependence on an economy based solely on crude oil exports and given the global crisis in oil prices, the need has arisen for new and creative strategies for more inclusive, proactive, multilateral, and sustainable peace and security planning and operations in West Africa. This will ensure that the burden of PSOs is equitably shared in order to strengthen collective ownership among the member states of ECOWAS. However, Nigeria's critical role in the establishment of ECOMOG and ensuring its effectiveness in its many interventions are some of 
the good examples from which other sub-regional organisations, such as IGAD, could learn.

\section{References}

Abubakar, A.A. (2009). Peacekeeping in West Africa: The Nigerian experience. In G.J. Jonah and I.S. Zabadi (Eds.), Peace support operations in the new global environment: The Nigerian perspective (pp. 177-198). Abuja: National Defence College.

Adebajo, A. (2002). Building peace in West Africa: Liberia, Sierra Leone and GuineaBissau. Boulder, CO: Lynne Rienner Publishers.

Adebajo, A. (2008). Hegemony on shoestring: Nigeria's post-cold war foreign policy. In Adekeye Adebajo and Abdul Raufu Mustapha (Eds.), Gulliver's troubles: Nigeria's foreign policy after the cold war (pp. 1-37). Scottville: University of Kwazulu-Natal Press.

Adedeji, A.G. (2007). Nigerian military and national interests in the 21 st century. In B.A. Akinterinwa (Ed.), Nigeria's national interests in a globalising world: Further reflections on constructive and beneficial concentricism, Volume two: Foreign policy in the innermost circle (pp. 176-207). Ibadan: Bolytag International Publishers.

Adeshina, R.A. (2002). The reversed victory: Story of Nigerian military intervention in Sierra Leone. Ibadan: Heinemann Educational Books (Nigeria) Plc.

Agwai, M.L. (2010). Nigeria's military capacity for regional and global peace support operations. Lecture delivered to participants of National Defence College, course 18, Abuja, March 30, 2010.

Ajibewa, A. (2007). Nigeria's foreign policy posture. In B.A. Akinterinwa (Ed.), Nigeria's national interest in a globalising world: Further reflections on constructive and beneficial concentricism, Volume two: Foreign policy interests in the innermost circle (pp. 1-30). Ibadan: Bolytag International Publishers.

Ajulo, S.B. (1998). Towards an interpretation of the notion of pax Nigeriana. Lagos: NIIA.

Akindele, R.A. (2003). ECOWAS, good governance and sub-regional security in West Africa. In R.A. Akindele (Ed.), Civil society, good governance, and the challenges of regional security in West Africa (pp. 271-333). Ibadan: Vantage Publishers.

Akinterinwa, B. (2010). Nigerian citizen diplomacy: Theoretical genesis and empirical exegesis. Ibadan: Bolytag.

Alli, W.O. (2012). The role of Nigeria in regional security policy. Abuja: FES.

Bamali, N. (2007). Redefining Nigeria's interest and commitments in peace support operations. In B.A. Akinterinwa (Ed.), Nigeria's national interests in a globalising world: Further reflections on constructive and beneficial concentricism, Volume Three: Nigeria's national interests beyond Nigeria (pp. 68-109). Ibadan: Bolytag International Publishers.

Bassey, C.O. (1993). Nigeria in ECOMOG: The dilemma of preventive diplomacy. In Jide Owoeye (Ed.), Nigeria in international institutions (pp. 163-176). Ibadan: College Press.

Bassey, C.O. (2011). The challenge of military statecraft in Nigeria. In Bassey, C.O. and Dokubo, C.O. (Eds.), Defence policy of Nigeria: Capability and context. A reader (pp 19-51). Bloomington, IN: Author's House.

Danjuma, T.Y. (2012). Nigeria's security role in West Africa. Online Nigeria. Retrieved January 6, 2012 from http://www.onlinenigeria.com/finance/?blurb=44. 
Deng, F.J. (2009). Peacekeeping in bad neighbourhood: The Economic Community of West Africa States (ECOWAS) in peace and security in West Africa. African Journal of Conflict Resolution, 9(3), 19-21.

Fawole, W. (2008). Militaries, militia and mullahs: National security issues in Nigeria's foreign policy. In Adekeye Adebajo and Abdul Raufu Mustapha (Eds.), Gulliver's Troubles: Nigeria's Foreign Policy after the Cold War (pp. 96-115). Scottsville, South Africa: University of KwaZulu-Natal Press.

FGN. (2006). Nigerian National Defence Policy. Abuja: Ministry of Defence, Federal Government of Nigeria (FGN).

Galadima, H.S. (2011). Nigeria in international peace keeping. In A. Oshita and O. Ogaba (Eds.), Nigeria in the global arena: Past present and future (pp. 301-328). Lagos: FOG Ventures.

Gambari, I.A. (2010). Politics and economics of peace support operations. Paper presented at a Ministry of Defence seminar on peace support operations and Nigerian foreign policy, Shehu Musa Yar Adua Centre, August 2-3.

Jonathan, G.E. (2011). Opening address of the president and commander-in-chief of the armed forces of Nigeria. Conference on the review of Nigeria's foreign policy organised by the Presidential Advisory Council (PAC) in Collaboration with the Ministry of Foreign Affairs (MFA). Conference Hall, MFA, Abuja, August 1-3.

Maduekwe, O. (2008). Minister of foreign affairs, keynote address. Workshop on Nigeria's response to a more secure Africa/Nigeria security interests in Africa, IPCR Auditorium, Abuja, May 2-8.

Malu, L. (2009). ECOMOG: A peacekeeping operation in perspective. In G.J. Jonah and I.S. Zabadi (Eds.), Peace support operations in the new global environment: The Nigerian perspective (pp. 159-176). Abuja: National Defence College.

McGregor, A. (2013). Nigerian army abandons peacekeeping missions in Mali and Darfur to combat Boko Haram. Terrorism Monitor, 81(15). Available at: https://www. refworld.org/docid/5204fb024.html [accessed 5 November 2020].

Obasanjo, O. (2007). Nigeria, Africa and the world in the next millennium. Statement by his excellency President Olusegun Obasanjo at the general debate of the $54^{\text {th }}$ session of the United Nations General Assembly, New York, September, 1999. In U.J. Ogwu and W.O. Alli (Eds.), Years of reconstruction: Selected foreign policy speeches of President Olusegun Obasanjo (pp. 35-42). Lagos: Nigerian Institute of International Affairs.

Oluwadare, A.J. (2013). The African Union and the conflict in Mali: Extra regional influence and the limitation of a regional actor. Journal of International Global Studies, 6(1), 106-120.

Pryce, P. (2013). Misadventure or mediation in Mali: The EU's potential role. Central European Journal of International Security Studies, 2, 22-39.

Sanda, J. (2003). The Cote d'Ivoire crisis: Implications for Nigeria. Being paper delivered to participants at the National War College, Abuja. 